\title{
Three characters in Polish jokes
}

\author{
Dorota Brzozowska
}

\begin{abstract}
The aim of this paper is to show how tripartite jokes have developed from ethnic jokes into jokes about professions. The attempt to answer the question about the universal and culture specific character of those jokes will be crucial. The introduction will present the relationships of the current topic with the number three as a folkloric universal. Stereotypical situations prompting the representatives of different nations to behave in a manner characteristic for them are then described, followed by the analysis of the entwining of ethnic, political, sexual, "logical" and other dimensions of humour in tripartite jokes.

The historical contexts and the role the closest and most relevant neighbours, i.e. the Russians and the Germans, play in Polish culture is presented and compared with the stereotypes and attitudes of other national characters present in jokes (e.g. Czechs, Americans). With this, we aim to answer the question if and when ethnic stereotypes are still present in contemporary jokes.
\end{abstract}

Keywords: three characters in jokes, Polish humour, targets, ethnic stereotypes, demotivators

The aim of this paper is to analyse the stereotypes present in Polish jokes about three characters. The researched material consists of four hundred jokes from books, booklets and the Internet. The comparison was made to show the difference between the texts from the beginning of the $20^{\text {th }}$ century and more recent jokes. The political situation in Poland after 1989 has changed rapidly; the subjects, forms and way of disseminating jokes have been altered as well.

The main issue that is different now from what it used to be before the transformation of 1989 is the number of jokes dealing with topics considered as taboo. It means e.g. more sexual humour, jokes about the clergy, and tasteless and sick disaster jokes about death with a growing popularity of black humour. The trend is connected with the loosening censorship and a tendency to cross the borders between the sacred and the profane in the name of the freedom of speech. The relatively recent possibility of publishing critical texts about politics in the regular media - papers, radio, television, and the Internet - was one of the reasons why political jokes (after flourishing during the period of communist 


\section{Dorota Brzozowska}

times) started to go into oblivion. The joke cycles making fun of the communist party and strictly connected with its leaders have disappeared. Presidents and prime ministers used to be the heroes of a great number of jokes, but nowadays the category of political humour is fuzzier. Some politicians have become the butts of individual short-lived jokes strictly connected with current issues discussed in the media. A new type of celebrity series appeared, but they do not make a stable group either and may be treated more as a part of fashion trends.

The fall of socialism, gained political freedom, the collapse of the Iron Curtain and finally joining the European Union have caused Polish popular culture to absorb certain trends very quickly from the formerly isolated and admired West. New cycles of jokes borrowed mainly from America are now present and the huge influence of the English language can be observed. The texts seem to be more connected with global issues and there are international subjects and foreign words in them. Many texts circulating among Polish teenagers are in English - as for the new generation English is a second language they start learning preschool and used in the everyday (Internet) communication.

The difference between the literary (upper) and common (lower) styles keeps disappearing and the democratisation/pauperisation of the language is seen in all communicative spheres - the trend could be noticed also in jokes present in contemporary Poland. There are many vulgar, aggressive and colloquial words used in them; subtle, elaborate language plays are rare and situational humour prevails.

Humour in everyday life has a new place and is present more frequently due to its easy dissemination enabled by the popularity of new media such as journals, tabloids, daily press, advertisements, and radio. Television and the Internet give numerous opportunities to create, duplicate and disseminate humour. The change from a society of words to a society of pictures also has its influence on the form of humorous genres. Jokes take the form of pictures or photos combined with some texts; short funny films and comic videos are created on an everyday basis; performances of amateur and professional cabaret groups can be watched online and sent to friends. All of these make jokes proliferate in many communicational spheres and in new shapes.

One of this paper's objectives is to follow the changes of one particular group of ethnic jokes in a more detailed way. This group of jokes is particularly important for Polish folk tradition as Poland was a multicultural country before the Second World War. Many different nationalities lived there and many languages were spoken. After the War under socialism the concept of one country, one language, and one nation was promoted. After the fall of communism in 1989, the idea of local identity, regional dialects and pride of local community and its culture has reappeared. The attitudes reflecting ethnic changes could also be 
observed in the jokes, which are full of stereotypes - a term coined from Greek as stereós - 'petrified, hard, stable' and týpos - 'type, picture, form' - seen both on the structural and semantic levels.

On the structural level traditionally the most popular ethnic cycle is based on "the rule of three", which is common in many folk texts and in different cultures (cf. Christie Davies's works on ethnic humour: 1990, 2005, 2011). Whereas for example in the British tradition, the heroes are an Englishman, an Irishman and a Scotsman and the motive is quite well-known worldwide and still used ${ }^{1}$, the famous Polish triad consists of a Pole, a Russian, and a German.

The earliest versions of the jokes from this group could be connected with a legend about three brothers Lech, Čech (or Czech) and Rus. They are known as the ones who founded the three Slavic nations: Lechia (Poland), Czechia (Bohemia, Moravia, Silesia - modern Czech Republic), and Ruthenia ('Rus' $\sim$ modern Russia, Belarus and Ukraine). There are multiple versions of the legend known in different countries. One of the Polish versions of the legend says that the three brothers went hunting together, but each of them followed a different prey and eventually they all travelled in different directions. Rus went to the east, Čech headed to the west to settle on the mountain rising up from the hilly Bohemian countryside, while Lech travelled north. There, while hunting, he followed his arrow and suddenly found himself face-to-face with a fierce white eagle guarding its nest from intruders. Seeing the eagle against the red of the setting sun, Lech took this sight as a good omen and decided to settle there. He named his settlement Gniezno (Polish gniazdo - 'nest') in the commemoration of this event and adopted the White Eagle as his coat-of-arms ${ }^{2}$. The earliest Polish mention of Lech, Čech and Rus is found in the "Chronicle of Greater Poland” written in 1295 in Gniezno or Poznań. In Bohemian chronicles, Čech appears on his own or with Lech only; he is first mentioned as Bohemus in Cosmas' chronicle (1125) (Wikipedia 20.05.2012).

The legend suggests the common ancestry of Poles, Czechs and Ruthenians and illustrates the fact that as early as the $13^{\text {th }}$ century, at least three different Slavic peoples were aware of being ethnically and linguistically interrelated, and, indeed, derived from a common root stock. The legend also attempts to explain the etymology of their ethnonyms - Lechia, the Czech lands, and Ruś (Wikipedia 20.05.2012).

1 The idea of three characters appears in different genres and is used also by contemporary authors, e.g. the first sign of the dangerous plot in which the joke producers try to eliminate those who could solve their mystery was the appearance of those three characters (i.e. an Englishman, an Irishman and a Scotsman) walking down the street and following the main character in Anthony Horowitz's novel "The Killing Joke" (2004).

2 The white eagle remains a symbol of Poland to this day, and the color of the eagle and the color of the setting sun are depicted in Poland's flag. 
The neighbouring Slavs were present in Polish folk texts, especially in those created in border areas. But in the mainstream jokes in the pre-war period the most popular characters of the Polish ethnic jokes were Jews as important coparticipants of the social life at that time. During the Second World War, the Allies and the Germans, and later, until the fall of communism, the Russians became the butts of ethnic jokes. Representatives of the last two nationalities, being the closest neighbours for centuries, appeared in classic Polish ethnic jokes with the central traditional series of the texts about "a Pole, a Russian and a German". In the period of the "Cold War", the Russians were accompanied by the Americans, who were presented as positive characters. In the newest jokes, the Americans have begun to take the dominant position. Either they complement the classic triad as a fourth character or replace a character of one of the other nationalities. In the traditional Polish jokes about the three characters, the Germans mainly take the middle position. Being the middle one, they are the ones who are rarely strongly characterised and they are not those who are targeted. Taking into consideration that the Pole is always the winning hero, and the Russian is the loser, the German thus stays in the middle as an easily replaceable ethnic character. A hierarchy of heroes in the classical Polish three nation jokes is similar to the one present in the following example:

There was a competition in driving nails into a board using one's head. There were three competitors: a Pole, a Russian and a German.

The German starts first: He hits one ... two ... three ... the nail has been driven in.

The Pole is next: one ... two ... stuck.

The last is the Russian:

One ... - stuck!

The results are announced:

The German is second, the Pole is first and the Russian is disqualified for sticking the nail in the wrong end.

(www.dowcipy.ugu.pl/dowcipypolak3.html, last accessed on 2 October 2012)

In the post-war period in Poland, when the traditional character cycle proliferated, jokes about some nationalities and ethnic groups started to fall into oblivion. Some jokes about Jews were replaced by texts about Scots, and some others, lacking the characteristic elements (e.g. the language ones), became absorbed by the texts of general circulation. However, in the recent years, the interest in Jewish culture has been revived, and so has Jewish jokelore to some extent. The representatives of some other nationalities, hardly ever mentioned in jokes earlier, have become more and more often the heroes of ethnic jokes. 
When Poland joined the European Union, EU officers and the nations of the EU member states began to turn up in more jokes. The interest in Asian cultures, their quick economic development and visibility on European markets caused the ethnic characters such as the Chinese and Japanese appear more frequently in Polish humorous texts.

Internet communication and increasing mobility have allowed these jokes to travel quickly to a global audience. Thanks to this, jokes about local communities are known on a wider arena, and jokes about different nationalities have begun to have a much wider circulation. Easy Internet access and the role it plays especially in young people's lives have resulted in the appearance and spread of many new genres of humorous texts. Especially, the role of combining visual means with funny ideas flourishes in the form of short YouTube amateur videos, and in demotivators, which is one of the most popular methods of creating and enjoying Internet humour (cf. Baran 2012; Piekot 2012). As the means and subjects of jokes have changed, it is interesting to look for the traces of the traditional "rule of three" and also the reminiscences of ethnic characters that appear in the new forms in contemporary humorous texts.

One of most prolific, new humorous genre is called a demotivator (or, alternatively, demotivational poster). It is a combination of a suggestive drawing or a photo with a commenting caption. Demotivators are mostly cynic or ironic. They started out as a parody of the motivational posters present in many (usually American) offices, which were supposed to motivate employees to work harder and achieve their targets. They spread very easily and quickly as commentaries and responses to hot media subjects.

Last year, one of the most important events for Polish mass media was the preparation of and then participation in the European Football Championships organised jointly by Poland and the Ukraine. EURO 2012 was interesting not only for regular fans but also for the entire nation, who could discuss the pros and cons of organising such a huge and expensive event. As sport events are very often a good reason and opportunity to revitalise and strengthen national identity, this particular competition was also good ground for the observation of ethnic related behaviours and the revival of ethnic stereotypes ${ }^{3}$.

The first funny (visual) comments appeared straight after it had been decided which teams would play in which groups. Interestingly enough, the traditional story of Slavic brotherhood was very easily recalled; it gained a new life and dimension in numerous demotivators.

3 The relations between humour and sport are discussed to a great extend in papers of Jan Chovanec (e.g. 2005). 

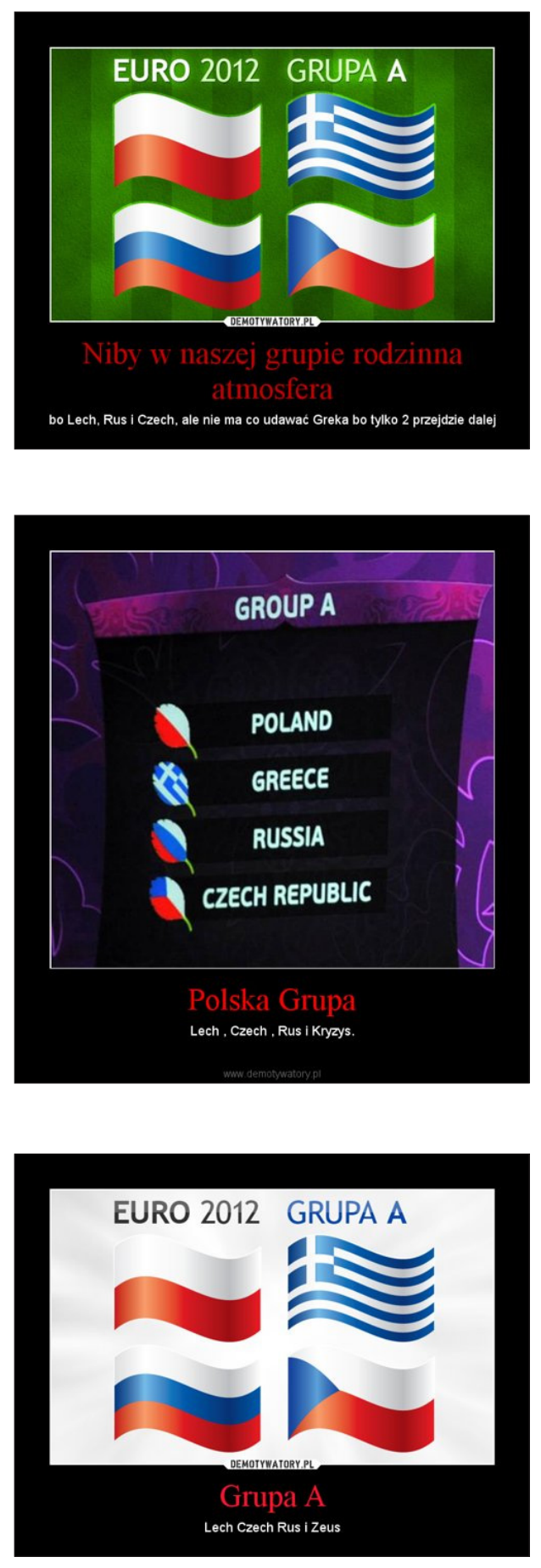

Figure 3. Grupa A. Group A (http: / /demotywatory.pl/3826521/Grupa-A, last accessed on 9 June 2012).

ish Group: Lech, Czech, Rus and Crisis".

In this demotivator Group A consists of the same four elements as in the previous one, namely Lech, Czech, Rus and an extra element, Zeus. But this time the brief name of the odd fourth one is alluding to the cultural background and the knowledge about 
the influential role of Greece in ancient times and its well-known mythological characters.

In all the above-mentioned demotivational posters, the core element was using the old form, pointing at the three traditional characters, alluding in a creative way to the legendary brothers. It is clearly visible when we consider the contemporary ethnic terms: Polak, not Lech, and Rusek, not Rus. The most creative part concerned the fourth character, which is an additional element. Using the rule of three, the authors of the first demotivator played with the Polish idiom udawać Greka ('play dumb'), or alluded to the hot subject of the crisis in Greece, coinciding with EURO 2012 (replacing words based on similar pronunciation). In the third example, the creative part is in evoking the myths from ancient Greek history taught at schools.

The fourth example is slightly different, both on the structural and topical levels. The demotivator uses two paintings and a photo of the stadium. The first picture by the famous $19^{\text {th }}$ century Polish painter, Jan Matejko, shows the Russian Tsar, Vasily IV Shuysky, brought by the Grand Hetman of the Crown, Stanisław Żółkiewski, and compelled to kneel before the Polish King, Sigismund III Vasa, at the Sejm in Warsaw on 29 October 1611. The painting commemorates the Polish-Muscovite War (1605-1618) part of which was a victory against the combined Russian and Swedish forces in the battle of Klushino and the presence of Polish troops in the Kremlin. Żółkiewski seized Moscow and took the Tsar Vasily Shuysky, and his brothers, Ivan Shuysky and Dmitri Shuysky, captive. The war finally ended in 1618 with the Truce of Deulino, which granted the Polish-Lithuanian Commonwealth certain territorial concessions, but not control over Russia which thus emerged from the war with its independence unscathed.

Figure 4. Nie wierze $w$ numerologię. I don't believe in numerology (http: / / demotywatory.pl / 3823901 / Niemam-przesadow-numerologicznych, last accessed on 8 June 2012). 1612 - The Poles govern the Kremlin; 1812 - The Poles together with the Napoleon's Army visit the Kremlin again; 2012 - 12 June Poland v Russia football match. I don't believe in numerology, but I wouldn't mind if the tradition continued.

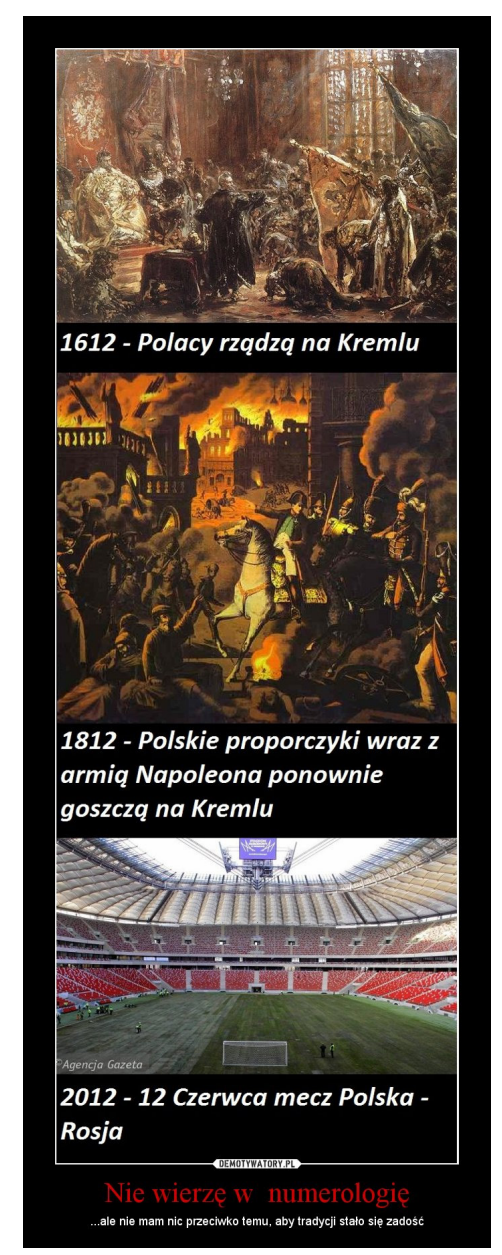


The second picture shows an oil painting by an unknown German artist painted in 1820s and entitled "The French in Moscow, 1812 (Napoleon)". It illustrates one of the incidents connected with the French invasion of Russia in 1812, also known as the Russian Campaign in France and the Patriotic War of 1812 in Russia. The campaign began on 24 June 1812, when Napoleon's forces crossed the Neman River. Napoleon aimed to compel the Emperor of Russia, Alexander I, to maintain the Continental Blockade of the United Kingdom; an official aim was to remove the threat of a Russian invasion of Poland. Napoleon named the campaign the Second Polish War. Figures on how many men Napoleon took into Russia and how many eventually came out vary rather widely but for sure Polish forces were present there. Napoleon crossed the Neman with over 600,000 soldiers, only half of whom were from France, the others being mainly Poles and Germans. After entering Moscow, the Grande Armée, unhappy with military conditions and no sign of victory, began looting what little remained in Moscow. The same evening, the first fires began to break out in the city, spreading over the next few days. Moscow, consisting in two thirds of wooden buildings at the time, burnt down almost completely (it was estimated that four-fifths of the city was destroyed) $)^{4}$. Both of these pictures ironically pointed out a short triumph followed by a great defeat.

The strong allusions to historical facts and political, not always friendly relations, and to the very few occasions when the Poles were the conquerors of their bigger neighbour are constructed in the form of a three picture section which emphasises the parallels and strengths of the power of wishful thinking about a spectacular, even if not lasting, victory, revealing the Polish-Russian relations in demotivators, making use of "the rule of three" on a structural level.

The traditional ethnic characters are evoked in a new type of jokes created in a particular situation in which the typical triad was contrasted with a fourth element. It means that there is a concept of three characters strongly present in mentality and cultural memory - even if it is not visible on an everyday basis, it is triggered easily and renewed in the proper circumstances. As for the structural triad, the presence of the three demotivators combined together is not a very common technique, but nevertheless, it does occur in some cases and then the parallels of certain situations are underlined and the punch line is more emphasised. Probably due to economic and visual reasons, there is the tendency of creating demotivators in a simplified version.

Ethnic jokes, although most popular, are not the only type of jokes about three characters. Traditionally, the representatives of different religions present in Poland were also pictured as discussing the things in this triad convention. It is usually a priest, a pastor and a rabbi debating different aspects of faith,

${ }^{4}$ http://en.wikipedia.org/wiki/French_invasion_of_Russia, last accessed on 9 October 2012. 
religion, customs and values, often trying to prove that their own beliefs are better than the ones of the others:

A priest, a pastor and a rabbi travelled on a train. The priest being tactful and the rabbi as a wise man did not start discussing sensitive subjects, but the pastor had a long tongue and started a dispute. Then, the rabbi said: "Mister Pastor! If the Messiah has not come yet, it means that we the Jews are right; if he has already come, the priest is right, but you are not right for sure."

(Ksiegga dowcipu [20th Century source without the date of publishing]: 385)

Some of the jokes with those characters are also relevant nowadays, especially the ones dealing with universal and eagerly discussed moral dilemmas and transcendental subjects:

A priest, a pastor and a rabbi are discussing the moment when human life starts.

Priest: "Human life starts at the moment when the ovarian cell is connected with a sperm cell."

Pastor: "Human life starts at the moment when a zygote finds its nesting place in a uterus."

And the rabbi responds: "Gents ... Human life starts at the moment when your wife dies and your dog dies and your children move out."

(rozrywka.57.pl/kaw-4-o,religii/2, last accessed on 28 September 2012)

The continuation of three-hero jokes and their ethnic character may also be found in texts about very rich new-Russians or businessmen, who sometimes can play the same role in the structurally similar texts:

Three rich businessmen discuss things while drinking alcohol. The first of them boasts:

"I have so much cash that I can buy the biggest telecom company for my daughter's birthday."

The second one says:

"I am also rich and I can buy all the telecom companies at once."

They look at their friend as he says nothing for a while and finally he says:

"Why are you staring at me? No way, I am not going to sell them to you ... " (http://dowcipy.pisze.se/ last accessed on 10 February 2012)

The characters in the above mentioned jokes, even if popular, usually occur sporadically in the jokes using the sequence of three parts and at most times do not form a cycle. 
Nowadays, only the cycle of a mathematician, a physicist and an IT engineer can be classified as a really proliferating group of three representing the category of three-character jokes under discussion.

An engineer, a physicist and a mathematician were given the same quantity of wire netting and the order to fence with it the largest possible area. The engineer fenced an area in the shape of a square. The physicist, as a little more intelligent person, fenced an area in the shape of an ideal circle and claimed that it is not possible to do it in a better way. The mathematician put up the fence carelessly, got inside and said:

"I am outside."

(http://naukowcy.dowcipy.pl, last accessed on 2 October 2012)

In the case of the interaction between the above mentioned groups, usually a mathematician plays a role of a wise man, though slightly disconnected from reality. This feature goes well with the stereotype of an absent-minded scientist living in a world of his own. A physicist is mostly down to earth, whereas the IT guy is the butt of the jokes, most likely because of the equipment he uses rather than due to the fact that he reveals certain character traits. Although these joke-heroes form the core of the cycle, sometimes it happens that one of them can be replaced by a representative of another related discipline:

An engineer, a chemist and an IT guy are travelling in the same car. Suddenly, their engine wheezes, squeaks and stops working.

"Something is wrong with the engine," says the engineer.

"The petrol is of poor quality," says the chemist.

"Let's get off and on and this may help," says the IT guy.

(http://naukowcy.dowcipy.pl, last accessed on 2 October 2012)

Three guys are watching a house. Suddenly, two persons enter the house. In half an hour three persons leave the house.

A biologist says: "They have bred."

A physicist says: "No, this is a measurement error."

A mathematician says: "If one more person enters the house, it will be empty ..."

(http://naukowcy.dowcipy.pl, last accessed on 2 October 2012)

The tendency to tell jokes about researchers in hard sciences as opposed to researchers in the humanities goes well with the broader trend reflected in the policy of the Polish Ministry of Science and Higher Education to support sciences more than humanities, e.g. by creating and offering a system of special scholarships for students who decide to take science courses ordered by 
the Ministry. People connected with the humanities are perceived as more old-fashioned and traditional. Not very frequently do the representatives of humanities and sciences appear together in a single joke - but when they do, their points of view are contrasted very well:

A mathematician, a physicist and a Polish philology researcher wonder which is better to have - a wife or a mistress.

The mathematician claims: "It is better to have a wife because my dinner is always cooked and the house is tidy."

The physicist says: "It is better to have a mistress - she always smells good and is eager to make love."

The Polish philology researcher responds: "It is best to have both. My wife thinks that I am at my mistress' and my mistress thinks that I am at my wife's - and I can get to the library ..."

\section{Conclusions}

Three-character jokes have changed much with passing time in accordance with the political and economic situation. First, the traditional triad involved a Pole, a Russian and a German. Somewhat later, they were accompanied or replaced by an American. Next some members of the EU started to appear in the jokes, and finally the Japanese and Chinese were introduced into the humorous texts. There have not been many jokes about Germans recently. The Russians occur in the context of their newly acquired status as very spoilt and extremely rich New-Russians. Only certain political issues, special situations or sport events are able to revitalise the ethnic stereotypes - as it happened during EURO 2012 when the teams of Poland's close neighbours played Poland or against each other. As the Polish team played Russia, historical antipathies were mentioned. In particular, the Russian fans wanted to organise a manifestation connected with their national festival. They submitted a request for permission to hold a march on 12 June 2012, which coincided with the football game between Poland and Russia and the Russian Independence Day. They declared that no political slogans would be used. However, that was not the case and during the march towards the National Stadium, riots broke out. Over 180 people were arrested. The Czech fans on the other hand were amazed how positive the attitude of the Polish was towards them ${ }^{6}$. Even after the losing match with the Czech team

5 The joke is also known in the version with a great symposium on the subject "Should man have a wife or a lover". A doctor, a psychiatrist and a scientist are answering this question respectively (http://www.dowcipowo.pl/grupa/geekowe/najlepsze-z-najnowszych, last accessed on 2 October 2012).

${ }^{6}$ Ziemowit Szczerek, Czesi nie mogą się nadziwić Polską. Historyczna zmiana stereotypu? http://fakty.interia.pl/tylko_u_nas/news/czesi-nie-moga-sie-nadziwic-polska-historyczna-zmiana,1810637, last accessed on 17 June 2012. 


\section{Dorota Brzozowska}

that put the Polish team out of the tournament, the Polish fans congratulated their Czech rivals, promising to cheer for their team. The idea of brotherhood and being together as Slavs was evoked in this case.

The national stereotypes are not present so visibly in everyday jokes any longer. The three-character jokes are more and more ethnically neutral. In addition, ethnic characters have changed. There is a bigger range of nations represented in jokes, but they do not create a particular series. The three-character jokes and their pattern are activated in the cycle of an IT guy, a mathematician and a physicist. It is difficult to define which character is most frequently in this new joke cycle. It is interesting how both - the classical one and the new cycles - have maintained their highly masculine character. Although the jokes about a Pole, a Russian and a German have a long history, a parallel cycle about women of different nationalities does not exist. There are only isolated examples of jokes about women from different cultural backgrounds, and there are some jokes about "a blonde, a brunette and a red-haired woman". Also the scientists are male and the stereotypes of the disciplines they represent are strictly connected with masculinity. Finally, not only have the main characters of the jokes changed, but the jokes are also usually shorter and in consequence the rule of the three is used nowadays to a smaller extent.

\section{References}

Baran, Anneli 2012. Visual humour on the Internet. In: L. Laineste \& D. Brzozowska \& W. Chłopicki (eds.) Estonia and Poland. Creativity and tradition in cultural communication,Vol. 1. Tartu: ELM Scholarly Press, pp. 171-186.

Brzozowska, Dorota 2008. Polski dowcip etniczny. Stereotyp a tożsamość. [Polish ethnic jokes. Stereotypes and identity.] Opole: Wydawnictwo Uniwersytetu Opolskiego.

Brzozowska, Dorota 2009. Polish jokelore in the period of transition. In: A. Krikmann \& L. Laineste (eds.) Permitted laughter: Socialist, post-socialist and never-socialist humour. Tartu: ELM Scholarly Press: pp. 127-169.

Brzozowska, Dorota \& Chłopicki, Władysław 2012 (eds.) Polish humour. Humour and culture 2. Kraków: Tertium.

Chovanec, Jan 2005. Czeching out puns and clichés in football reporting. Theory and practice in English studies. Brno: Masarykova Univerzita, Volume 3, pp. 61-67.

Davies, Christie 1990. Ethnic humor around the world. A comparative analysis. Indiana: Indiana University Press.

Davies, Christie 2005. Jokes and groups. London: Institute for Cultural Research.

Laineste, Liisi \& Brzozowska, Dorota 2011. Eastern European three-nation jokes: A beta database. In: A. Witalisz (ed.) Papers on Culture, Language and Literature 3. Prace Naukowo-Dydaktyczne Państwowej Wyższej Szkoty Zawodowej w Krośnie 55. Krosno: PWSZ Krosno, pp. 115-126. 